\title{
Calf health from birth to weaning. I. General aspects of disease prevention
}

Ingrid Lorenz ${ }^{1 *}$, John F Mee ${ }^{2}$, Bernadette Earley ${ }^{3}$ and Simon J More ${ }^{1,4}$

\begin{abstract}
Calfhood diseases have a major impact on the economic viability of cattle operations. This is the first in a three part review series on calf health from birth to weaning, focusing on preventive measures. The review considers both pre- and periparturient management factors influencing calf health, colostrum management in beef and dairy calves and further nutrition and weaning in dairy calves.
\end{abstract}

Keywords: Calf health, Prevention, Periparturient management, Colostrum, Dairy calf nutrition

\section{Introduction}

Calfhood diseases have a major impact on the economic viability of cattle operations, due to the direct costs of calf losses and treatment and the long term effects on performance [1]. Calf health was prioritised as one of the most important animal health issues facing the Irish livestock industry in a recent expert Policy Delphi study conducted on behalf of Animal Health Ireland (AHI) [2]. AHI was founded in 2009 as an industry-led, notfor-profit partnership between livestock farmers, processors, service providers and government, with the goal to improve the profitability, sustainability and competitiveness of Irish livestock farmers and related industries through superior animal health.

As part of ongoing AHI work, a group of experts was commissioned to provide evidence-based advice on calf health and disease management to Irish farmers, agricultural advisers and veterinary practitioners. As an initial step, a three-part review series on calf health from birth to weaning has been generated, specifically to provide a scientific evidence base for the development of advisory tools on calf health, and to identify gaps in current knowledge to be filled with targeted research. Even though the envisaged output will be specific for Irish husbandry systems, the scope of the reviews should make them useful for the same purpose elsewhere. The reviews cover both suckler and dairy calf management. However,

\footnotetext{
* Correspondence: Ingrid.Lorenz@ucd.ie

${ }^{1}$ Herd Health and Animal Husbandry, UCD School of Agriculture, Food Science and Veterinary Medicine, University College Dublin, Belfield, Dublin 4, Ireland

Full list of author information is available at the end of the article
}

due to the differences in the nature of these systems, some topics will deal mainly or exclusively with either dairy or suckler calves. This first part highlights issues relating to disease prevention in calves, with emphasis on the periparturient period, calving management, care of the newborn, colostrum management and further nutrition and weaning. The second and third parts focus on the management of diarrhoea in pre-weaned calves [3] and disease prevention and management with particular reference to calf pneumonia [4].

\section{Preparturient management factors influencing calf viability and health}

Perinatal mortality is a problem in all eutherian species but particularly so in Holstein-Friesian-dominated dairy industries internationally [5]. Modifying preparturient management to improve calf viability and health is best achieved through implementation of simple protocols which document the correct strategies to be followed at the herd level and the correct procedures to be carried out at the individual animal level [6]. In addition, decisions taken earlier in the production cycle can influence calf viability, for example, choice of sire and sire breed, particularly beef breeds, use of sexed semen, age and weight at service in heifers, vaccination of the dam and nutrient intake in early pregnancy.

\section{Nutritional management in the last trimester}

During the last trimester, adequate energy and protein should be provided whilst avoiding overfeeding in heifers to prevent foetal oversize, excess adipose deposition 
in the birth canal and resultant dystocia [7]. Preventing excess body condition score (BCS) in heifers prior to calving (target BCS of 2.75-3.0; scale 1-5) also has a significant beneficial effect on both the duration of parturition and incidence of perinatal mortality $[8,9]$. In contrast, cows losing excessive BCS may be carrying twins and should be dried off early, fed to maintain body condition and monitored for obstetrical complications at calving. In addition, placing beef heifers and cows on a straw diet prepartum to prevent potential dystocia can lower the immune status of both their colostrum and of their calves [10]. Where the basal diet consists of home-grown forage, commonly in beef suckler herds, this may necessitate additional supplementation of micronutrients to ensure adequate foetal nutrition [11]. In dairy herds, reducing the dietary cation anion difference (DCAD) in the transition period has been shown to affect a linear decrease in the incidence of milk fever [12] and hence can reduce the risk of slow calvings and compromised perinates. Where congenital joint laxity and dwarfism (CJLD) has been diagnosed, typically in beef suckler calves [13], dilution of the silage-only diet with alternative forages or grains is recommended.

\section{Pharmacological induction of parturition}

If oversized calves are a problem based on previous experience, induction of parturition using dexamethasone at term can be used to deliver foetuses alive without any increase in dystocia [14]. Where induction of parturition has traditionally been practised in dairy cattle, there has been increased loss of calves, retained placenta and reduced milk production. This is, however, associated with early induction, not induction at term $[15,16]$.

\section{Calving management factors influencing calf viability and health}

The tenets of good calving management to improve calf viability and health are provision of a suitable maternity site, adequate but not intrusive calving supervision, correct obstetrical techniques and judicious utilisation of veterinary assistance. The importance of these factors was highlighted by a large-scale study of parturient problems in Friesian heifers which concluded that the primary determinant of whether a herd had high or low perinatal mortality was the quality of calving management [17].

\section{Maternity facilities}

The design and availability of specialised maternity accommodation can have a significant bearing on calving outcomes, as reviewed recently by Mee [18]. In addition, maternity facilities can significantly impact calf health. Dairy calves born in maternity pens are less likely to develop diarrhoea than those born in non-maternity facilities (loose housing or stanchions) [19]. Individual (vs. group) maternity pens have been associated with increased calf plasma immunoglobulin concentration and reduced risk of enteric and respiratory disease in most [20-22] but not all studies [23]. Irrespective of the type of maternity facility, early removal of the calf (before standing) has been recommended to reduce calfhood morbidity and mortality on dairy farms in the USA [24].

The principal function of a maternity site is to simulate as closely as possible natural calving conditions as is the norm for extensively managed beef suckler cows. To simulate natural calving conditions for intensively managed dairy cows they should be moved to maternity accommodation prior to the onset of calving though studies comparing this with moving once calving has commenced have not been published. Counter intuitively, moving pregnant dairy cows and heifers later in the calving process when the placenta or fetal hooves are visible can reduce the odds of perinatal mortality compared to moving them earlier when mucus only is visible [25]. These results suggest that it is less detrimental to move animals which have already commenced calving (stage two) than it is to move animals which are about to start calving (stage one). It is likely that environmental disturbance, such as moving an animal, may cause psychogenic uterine atony if initiated in stage one of calving, but may only cause a temporary decrease in uterine motility if initiated in stage two. However, this strategy requires $24 \mathrm{~h}$ monitoring of the 'close-up group' with approximately hourly checks and it is not clear whether this policy may interrupt the calving process and lead to more calving problems than if these animals were not moved or were moved before stage one commenced.

\section{Calving supervision}

Good calving supervision involves being present to assist during stage two of calving or to call for veterinary assistance, if required but not intervening unnecessarily. The day and time of calving is best predicted from altered behaviour such as increased frequency of rising and lying down, pawing with the forefeet and urinating and pelvic ligament relaxation [26]. Whilst there have been some interesting recent research developments in prediction of [27] and altering of the onset of calving in dairy cows [28] these have not yet been widely applied commercially. Lack of supervision can lead to perinatal death due to prolonged calving with resultant anoxia [29] or acidosis, which can predispose neonates to failure of passive transfer of colostral immunoglobulins [30]. The relevance of good calving supervision is highlighted by a survey of cow-calf operations in the US which showed that the majority of calvings did not take place in specialised maternity units and the majority of producers left heifers and cows calving for too long [31]. Intervention is generally recommended if the 
second stage of calving exceeds $2 \mathrm{~h}$ [32]. Tocolytic agents, such as clenbuterol, have been used successfully to both postpone night calvings and manage dystocia, but are not available in all jurisdictions. Various calving alarms have been developed to alert farmers to the time of calving such as biosensors that monitor postural behaviour, intravaginal or reticular temperature, vaginal mucus electrical resistance, myometrial contractions or tail elevation, but none are widely used commercially.

\section{Obstetrical technique}

Training of farm staff with protocols for various obstetrical problems should be part of the role of modern veterinary practitioners in the transfer of technical knowledge [33], as although almost a third of calvings are assisted, less than $3 \%$ are attended by veterinarians [34]. Farmers with good obstetrical technique can prevent iatrogenic traumatic lesions, a major cause of perinatal mortality, particularly now that mechanical traction is commonly employed at calving. For example, recent research has shown that alternate limb traction should be applied until both elbows have entered the pelvis and simultaneous traction should then be applied to reduce the risk of trauma to the calf [35].

\section{Care of the newborn calf to prevent poor viability and ill-health}

The emergency medicine concept of the 'golden hour' can be applied to at-risk newborn calves. This term refers to the principle of rapid intervention to prevent subsequent sequelae. High risk calves can be identified (a) before birth by the predicted likelihood of suffering from dystocia; (b) during birth by large forelimbs, swollen tongue, cyanosed muzzle and gums; or (c) after birth by apnoea or dyspnoea, lateral recumbence, flaccid musculature and poor pedal and suck reflexes. The triage approach to paediatric care of the at-risk bovine perinate in the first hour of life involves etho-physical assessment, resuscitation as necessary, umbilical antisepsis and colostrum feeding.

\section{Assessment of newborn calf vitality}

The vigour of the newborn calf can be assessed immediately after calving by monitoring individual indicators (responsiveness to exogenous stimuli, muscle tone, sucking reflex, time to head lift and time to first standing) or a combination of indicators in a calf vigour score [36]. A calf should normally lift its head, attain sternal recumbency and attempt to stand and to stand spontaneously, on average, 3, 5, 20 and 60-90 minutes after birth, respectively $[37,38]$.

\section{Calf resuscitation}

Immediately after birth, calves suffering from mild fetal asphyxia should be hypothermally stimulated by pouring cold water over the head then suspended upside-down for up to a minute $[39,40]$. Once a patent airway has been established, the at-risk calf should be placed in sternal recumbence [39]. Mechanical ventilation should be implemented in cases which do not respond to these first aid measures [41]. While the clinical benefits of some pharmacological stimulants in newborn calves are equivocal, doxapram has recently been shown to be beneficial in cases of fetal asphyxia [42]. Buffer solutions containing sodium bicarbonate have safely been used recently to improve the acid-base status in acidotic perinatal calves [43]. Oxygen therapy for calf resuscitation is possible, even though not widely practised on commercial dairy or beef farms. A positive effect of this measure on perinatal survival has only been proven in cases of respiratory distress syndrome in calves born immature [44].

\section{Umbilical care}

Prevention of omphalitis or 'navel ill' is based on good maternity pen hygiene, reducing calf residency time in unhygienic calving pens, ensuring adequate early intake of good quality colostrum and navel antisepsis [45]. In a recent review of navel care in perinates, Mee [29] concluded that producers should avoid possibly harmful cord application procedures and concentrate on maternity pen hygiene and calf immunity. In herds with serious navel-ill problems, producers should improve maternity pen hygiene, institute immediate and repeated cord dipping with chlorhexidine [46], removal of the calf immediately after birth to a clean calf pen, hand-feeding colostrum and regular checking for navel ill with metaphylactic parenteral antimicrobial therapy based on veterinary advice as necessary.

\section{Colostrum management}

Due to the structure of the bovine placenta, the calf is born without protective immunoglobulins (Ig) and therefore depends on the successful passive transfer of maternal Ig from colostrum. Multiple studies have shown that failure of passive transfer (FPT, serum IgG $<10 \mathrm{~g} / \mathrm{L}$ [47]) markedly increases morbidity and mortality in dairy and in beef calves (e.g. [10,48-52]. Besides immunoglobulins, colostrum provides a variety of other important ingredients like cytokines and growth factors as well as a superior nutritional value compared with whole milk [47].

In general, adequate passive transfer is subject of the quality of colostrum, the calf's ability to absorb Ig and the volume ingested.

The quality of colostrum in beef breeds is generally better than in dairy breeds and with average values in most studies well above $100 \mathrm{~g} / \mathrm{L}$ good enough to provide adequate passive transfer, as long as supervision is provided to ensure colostral intake [10,52-54]. 
Lactation number, breed of cow and length of the nonlactating period (if less than 3 weeks) influence volume and Ig concentration of colostrum in dairy cows [55-57]. Mean colostral IgG concentrations of $68.5 \mathrm{~g} / \mathrm{L}$ in Holstein cows were recently reported, whereby $32 \%$ of cows had poor colostrum quality $(<50 \mathrm{~g} / \mathrm{L})$ if milked within $1 \mathrm{~h}$ after calving. Pluriparous cows had higher IgG concentrations than primiparous cows in some, but not all studies [10,58-60]. Colostral IgG concentration decreases by $3.7 \%$ during each subsequent hour post calving; therefore, time of first milking is the most crucial factor regarding colostrum quality that the producer can influence [61]. The benefit of testing of colostrum quality on farm with commercially available hydrometers is controversial [47]. It appears to give good results only if the cut-points are adjusted for the specific device used [58]. More reliable results can be achieved using refractometry [62]. Pooling of colostrum lowers quality due to dilution and is also discouraged for reasons of biosecurity, e.g. transmission of Mycobacterium avium subsp. paratuberculosis [47].

Vaccination of the dam as a measure to increase specific antibody levels in colostrum will be discussed in the second part of this review [3].

The ability of the neonate to absorb IgG starts to decline progressively after 4 to $6 \mathrm{~h}$ and ceases after $24 \mathrm{~h}$ from birth $[63,64]$. Therefore, the earlier a calf is fed/suckles after birth, the greater the level of Ig absorption. Continuous feeding of smaller amounts of colostrum throughout the first two weeks of life has been associated with reduced diarrhoea in dairy calves, most probably due to local effects in the intestines [65].

It is currently recommended that normal sized dairy calves (Holstein-Friesian) are given either $3 \mathrm{~L}$ of good quality colostrum within $2 \mathrm{~h}$ of birth by oesophageal tube [59] or at least $3 \mathrm{~L}$ within $4 \mathrm{~h}$ and a total of $4 \mathrm{~L}$ within $12 \mathrm{~h}$ from birth by nipple feeding [60]. The amount of colostrum that calves drink voluntarily does not change within the first $4 \mathrm{~h}$ after birth, so that there is no benefit in delaying first feeding [60]. Feeding colostrum by stomach tube ensures successful passive transfer if high volumes are given $[66,67]$. However, if smaller volumes are given and the amount of immunoglobins administered is marginal it should be fed by nipple bottle, since the absorption of immunoglobulins in this situation is superior to that of stomach tubed calves [67]. In the US feeding colostrum by oesophageal feeder is used as a routine measure in about $14 \%$ of dairy heifer calves [68]. In Europe the discussion surrounding force-feeding colostrum is somewhat controversial, and further complicated by the fact that animal welfare legislation in some countries prohibits force feeding of animals except for medical reasons [69].

Suckling as a means of colostrum intake is associated with a higher risk of FPT compared with supervised feeding $[69,70]$.
Bacterial contamination of colostrum occurs frequently on many dairies, with two associated concerns; a risk of transfer of infection and decreased absorption of IgG in the intestines. Total bacterial count should not exceed 100,000 colony forming units $(\mathrm{cfu}) / \mathrm{mL}$ and faecal coliforms should be below 10,000 $\mathrm{cfu} / \mathrm{mL}$ [24]. In practice, these goals can be achieved by means of hygienic harvesting, avoidance of bacterial contamination, as well as immediate refrigeration or freezing of surplus colostrum [24]. Routine pasteurisation methods (as recommended for whole milk) lead to reduced IgG concentrations $[71,72]$ and increased viscosity [73]. Heat treatment at $60^{\circ} \mathrm{C}$ for $30 \mathrm{~min}$ reduces bacterial count, preserves IgG concentration and increases the apparent efficiency of absorption of IgG [74].

Colostrum replacement products (CR) are available for use if maternal colostrum is not available or is not given for biosecurity reasons. The efficacy of whey protein concentrate (WPC), used as a colostrum substitute and administered as a single feeding to dairy calves, was poor in preventing neonatal morbidity and mortality compared with a single feeding of pooled colostrums [75]. Studies evaluating the efficacy of commercial CR to prevent FPT in calves have produced very mixed and often unacceptable results [76]. Smith and Foster [77] concluded that simply examining the mass of IgG provided by the CR is not an adequate measure or predictor of product efficacy.

Frozen colostrum can be stored at -18 to $-25^{\circ} \mathrm{C}$ for at least a year without changing its quality. Slow thawing at temperatures below $50^{\circ} \mathrm{C}$ does not affect colostrum quality, while temperatures above $50^{\circ} \mathrm{C}$ cause colostral proteins, including immunoglobulins, to denature [78,79].

Direct tests for measurement of IgG concentrations are reliable, but laboratory-based and relatively expensive. The accuracy of many indirect tests (sodium sulphite turbidity, zinc sulphate turbidity test, $\gamma$-glutamyl transferase (GGT) activity, whole-blood glutaraldehyde coagulation test) has been questioned $[80,81]$. The measurement of serum total protein by refractometer is the most reliable test for herd screening, based on a review by Weaver et al. [81]. A serum protein concentration of $52 \mathrm{~g} / \mathrm{L}$ was found to be equivalent to $10 \mathrm{~g} / \mathrm{L}$ serum IgG and is suggested as test threshold for healthy calves up to an age of 8 days [80].

\section{Further nutrition and weaning of the dairy calf}

Traditionally, dairy calves have been fed milk or milk replacer to an amount of approximately $10 \%$ of the calf's body weight (BW) per day [82]. This level of nutrition ('restricted feeding') allows only for maintenance requirements and minimal weight gain under thermo-neutral conditions [83]. Restricted feeding was introduced to encourage calves to eat concentrates as early as possible and thus to minimise costs for relatively expensive liquid 
feeds. After the first 3 weeks of life, starter concentrate intake increases and the calves start to grow rapidly [84]. It has been known for a long time that calves can grow a lot faster if they are supplied with more nutrients $[85,86]$. However, worldwide interest in early calf nutrition has only recently been heightened, based on research from Diaz et al. [87] and Jasper and Weary [82], among others. Calves suckling their dam or otherwise fed ad libitum ingest about $20 \%$ of body weight (BW) per day and reach up to $1 \mathrm{~kg}$ of daily weight gain $[86,88]$. Furthermore, high volumes of milk or milk replacer fed to young calves do not cause diarrhoea; therefore, nutritional diarrhoea is a consequence of either inadequate quality of the liquid feed or of management failures (e.g. $[82,87,89,90]$ ).

Starter concentrate intake is negligible in the first 3 weeks of life. Therefore, calves on restricted feeding regimes are at most only able to achieve $20-30 \%$ of their biologically normal growth [91]. It is well established that under-nutrition in humans impairs the immune response [92]. In calves, a higher plane of nutrition improves immune function [93] and also lowers mortality and the incidence of diarrhoea and pneumonia [94-96].

A report on calf welfare [97] states that animal welfare is poor if average growth is reduced substantially, for example by $50 \%$. Data are insufficient at this time to determine the overall economic benefit of feeding systems that allow normal biological growth. An intermediate volume of milk (approximately $15 \%$ of BW) is sufficient to allow calves to reach over $50 \%$ of their growth capacity under moderate weather conditions [83]. Also, these amounts of liquid feed can be provided in systems with twice a day feeding without exceeding the abomasal capacity.

The choice of liquid feed usually depends on availability and producer preferences. Feeding of non-saleable ('waste') milk is recognised as a risk factor for the transmission of infectious pathogens and it should therefore be pasteurised $[95,98]$. Feeding milk containing antibiotic residues from treated cows increases the risk of development of antibiotic resistance [99]. Milk replacers are lower in energy content than whole milk and vary widely in composition and quality. Products containing non-milk proteins are not suitable for very young calves [100]. Since the protein requirements increase rapidly with increased growth rates, products with increased concentration of crude protein (25-27\%) should be used in programmes seeking normal or near-normal biological growth [101].

Most commonly, dairy calves are provided with liquid feed twice daily. No difference in calf performance between once or twice daily feeding was found when calves were raised on restricted feeding systems $[102,103]$. However, once-daily feeding will present problems if calves are fed for normal or near-normal biological growth in the first weeks of life: the volume of liquid feed provided would pose a high risk of overloading the abomasum if given in one feed [97]. On Irish dairy farms, Gleeson et al. [104] found no significant advantages in labour input either during feeding or in overall calf care between once-daily, twice-a-day or ad libitum feeding systems. Currently, relevant European legislation (laying down minimum standards for the protection of calves) demands that calves are fed at least twice daily (Council Directive 2008/119/EC, 2008). Consistent with the European Convention for the protection of animals kept for farming purposes (Appendix C: Special provisions for calves, 1993), this can only refer to feedings of milk or milk replacer in the young calf, since calves are totally dependent on liquid feed for at least the first three weeks of live.

Independent of the feeding system concentrates and water should be provided to calves at all times to enhance development of ruminal digestion. The amount of milk fed can then be reduced to $10 \%$ of BW at 3 weeks of age without any known negative impact $[96,105]$. Consumption of concentrates enables the development of ruminal epithelium necessary for the calf to digest solid feed. Additional forage feeding has no added value in calves bedded on clean straw that receive a calf starter concentrate with adequate coarseness (approximately 2,000 $\mu \mathrm{m}$ ) [106]. Calves can be weaned once they consistently consume $1 \mathrm{~kg}$ of concentrates per day. This level of intake can usually be reached at an age of 5 to 6 weeks if access to palatable starter and water is available ad libitum [79]. To assure constant growth rates, weaning should preferably be introduced gradually with a decrease of volumes of liquid feed provided over a period of some days $[107,108]$.

\section{Conclusions}

There are a broad range of preventive measures that are fundamental to optimal calf health during the period from birth to weaning. An emphasis on prevention is critical, limiting the need for subsequent intervention, particularly with the management of diseases of the gastrointestinal and respiratory systems. This review highlights preventive measures from birth to weaning, as well as the preceding periparturient period.

\section{Acknowledgements}

The authors from Animal Health Ireland's Technical Working Group (TWG) on Calf Health would like to thank the remaining colleagues of the TWG for their valuable input: Mary Canty (Centre for Veterinary Epidemiology and Risk Analysis, UCD School of Veterinary Medicine, University College Dublin, Belfield, Dublin 4, Ireland; Department of Agriculture, Fisheries and Food, Kildare St, Dublin 2, Ireland), Charles Chavasse (Pfizer Animal Health,

Riverwalk, National Digital Park, Citywest Business Campus, Dublin, Ireland), John Fagan (Department of Agriculture, Fisheries and Food, Regional Veterinary Laboratory, Coosan, Athlone, Co. Westmeath, Ireland), Richard J. Fallon (Castleknock Green, Castleknock, Dublin, Ireland), Liam Gannon (Volac Ireland, Church St, Killeshandra, Co. Cavan, Ireland), John Gilmore (Emlagh Lodge Veterinary Centre, Elphin, Co. Roscommon, Ireland), Ian Hogan 
(Department of Agriculture, Fisheries and Food, Regional Veterinary Laboratory, Knockalisheen, Limerick, Ireland), Emer Kennedy (Animal and Grassland Research and Innovation Centre, Teagasc Moorepark, Fermoy, Co. Cork, Ireland).

\section{Author details}

'Herd Health and Animal Husbandry, UCD School of Agriculture, Food Science and Veterinary Medicine, University College Dublin, Belfield, Dublin 4. Ireland. ${ }^{2}$ Animal and Grassland Research and Innovation Centre, Teagasc Moorepark, Fermoy, Co. Cork, Ireland. ${ }^{3}$ Animal and Bioscience Research Department, Teagasc, Animal and Grassland Research and Innovation Centre, Grange, Dunsany, Co. Meath, Ireland. ${ }^{4}$ Centre for Veterinary Epidemiology and Risk Analysis, UCD School of Agriculture, Food Science and Veterinary Medicine, University College Dublin, Belfield, Dublin 4, Ireland.

\section{Authors' contributions}

IL, JM and BE drafted the manuscript and compiled the literature. All authors made substantial inputs to the review, critically discussed the progressing manuscript and approved the final manuscript.

\section{Conflict of interest statement}

None of the authors of this paper has a financial or personal relationship with other people or organisations that could inappropriately influence or bias the content of the paper. The Technical Working Group includes employees of Pfizer Inc. (CC) and Volac Ireland (LG); these companies played no role in the design, development or journal submission of this review series.

Received: 12 July 2011 Accepted: 16 September 2011

Published: 16 September 2011

\section{References}

1. Donovan GA, Dohoo IR, Montgomery DM, Bennett FL: Calf and disease factors affecting growth in female Holstein calves in Florida, USA. Prev Vet Med 1998, 33:1-10.

2. More SJ, McKenzie K, O'Flaherty J, Doherty ML, Cromie AR, Magan MJ: Setting priorities for non-regulatory animal health in Ireland: results from an expert Policy Delphi study and a farmer priority identification survey. Prev Vet Med 2010, 95:198-207.

3. Lorenz I, Fagan J, More SJ: Calf health from birth to weaning. II. Management of diarrhoea in pre-weaned calves. Ir Vet J, Sep 142011 , 64(1):9.

4. Lorenz I, Earley B, Fallon R, Gilmore J, Hogan I, Kennedy E, More SJ: Calf health from birth to weaning. III. Disease prevention and management with particular reference to calf pneumonia. Ir Vet $J 2011$, in press.

5. Mee JF, Berry DP, Cromie AR: Prevalence of, and risk factors associated with, perinatal calf mortality in pasture-based Holstein-Friesian cows. Animal 2008, 2:613-620.

6. Boersema S-J, Cannas da Silva J, Mee JF, Noordhuizen J: Perinatal disorders. Farm Health and Productivity Management of Dairy Young Stock Wageningen Academic Publishers, The Netherlands; 2010, 135.

7. Mee JF: Prevalence and risk factors for dystocia in dairy cattle: a review. Vet J 2008, 176:93-9101.

8. Chassagne M, Barnouin J, Chacornac JP: Risk factors for stillbirth in Holstein heifers under field conditions in France: a prospective survey. Theriogenology 1999, 51:1477-1488.

9. Dimitrov M, Mitev J, Gergovska Z, Miteva T, Vasilev N: Relationship between the duration of the parturition phases of dairy cows, body condition and the postpartum uterine inflammations. Bulg J Agric Sci 2000, 6:455-462.

10. McGee M, Drennan MJ, Caffrey PJ: Effect of age and nutrient restriction pre partum on beef suckler cow serum immunoglobulin concentrations, colostrum yield, composition and immunoglobulin concentration and immune status of their progeny. Irish J Agr Food Res 2006, 45:157-171.

11. Mee JF, Rogers PA, O'Farrell KJ: Effect of feeding a mineral-vitamin supplement before calving on the calving performance of a trace element deficient dairy herd. Vet Rec 1995, 137:508-512.

12. Mulligan FJ, Doherty ML: Production diseases of the transition cow. Vet J 2008, 176:3-9

13. Mee JF: Nonhereditary disproportionate dwarfism in a beef herd: Clinical and pathological features. Ir Vet J 1995, 48:93-105.
14. Villarroel A, Lane VM: Effect of systematic parturition induction of long gestation Holstein dairy cows on calf survival, cow health, production, and reproduction on a commercial farm. Can J Vet Res 2010, 74:136-144.

15. Morton $\mathrm{JM}$, Butler $\mathrm{KL}$ : The effects of induced parturition in dairy cows on the incidence of mortality in calves from commercial herds in southwestern Victoria. Aust Vet J 1995, 72:5-7.

16. Mansell PD, Cameron AR, Taylor DP, Malmo J: Induction of parturition in dairy cattle and its effects on health and subsequent lactation and reproductive performance. Aust Vet I 2006, 84:312-316.

17. Drew B: Causes of dystokia in Friesian dairy heifers and its effects on subsequent performance. Annual Meeting of the British Cattle Veterinary Association; Brentford 1988, 143-151.

18. Mee JF: Newborn dairy calf management. Vet Clin North Am Food Anim Pract 2008, 24:1-17.

19. Curtis CR, Erb HN, White ME: Descriptive epidemiology of calfhood morbidity and mortality in New York holstein herds. Prev Vet Med 1988, 5:293-307.

20. Svensson C, Lundborg K, Emanuelson U, Olsson S-O: Morbidity in Swedish dairy calves from birth to 90 days of age and individual calf-level risk factors for infectious diseases. Prev Vet Med 2003, 58:179-197.

21. Garber LP, Salman MD, Hurd HS, Keefe T, Schlater JL: Potential risk factors for Cryptosporidium infection in dairy calves. J Am Vet Med Assoc 1994, 205:86-91

22. Michanek P, Ventorp M: Passive immunization of new-born dairy calves on three farms with different housing systems. Swed J Agric Res 1993, 23:37-43.

23. Pithua P, Wells SJ, Godden SM, Raizman EA: Clinical trial on type of calving pen and the risk of disease in Holstein calves during the first 90 d of life. Prev Vet Med 2009, 89:8-15.

24. McGuirk SM, Collins M: Managing the production, storage, and delivery of colostrum. Vet Clin N Am: Food Anim Pract 2004, 20:593-603.

25. Carrier J, Godden S, Fetrow J, Stewart S, Rapnicki P: Predictors of stillbirth for cows moved to calving pens when calving is imminent. J Dairy Sci 2006, 89(Suppl. 1):195.

26. Wehrend $A$, Hofmann $E$, Failing $K$, Bostedt $\mathrm{H}$ : Behaviour during the first stage of labour in cattle: Influence of parity and dystocia. Appl Anim Behav Sci 2006, 100:164-170.

27. Cangar O, Leroy T, Guarino M, Vranken E, Fallon RJ, Lenehan JJ, Mee JF, Berckmans D: Model-based calving monitor using real time image analysis. In Precision Livestock Farming '07. Edited by: Cox S. Wageningen Academic Press; 2007:291-298.

28. Gleeson $D, O$ 'Brien $B$, Mee J: Effect of restricting silage feeding prepartum on time of calving, dystocia and stillbirth in Holstein-Friesian cows. Ir Vet J 2007, 60:667-671.

29. Mee JF: Bovine perinatology: Current understanding and future developments. In Animal Reproduction: New Research Developments. Edited by: Dahnof LT. Nova Science Publishers; 2009:67-106.

30. Besser TE, Szenci O, Gay CC: Decreased colostral immunoglobulin absorption in calves with postnatal respiratory acidosis. J Am Vet Med Assoc 1990, 196:1239-1243.

31. Dargatz DA, Dewell GA, Mortimer RG: Calving and calving management of beef cows and heifers on cow-calf operations in the United States. Theriogenology 2004, 61:997-991007.

32. Gundelach Y, Essmeyer K, Teltscher MK, Hoedemaker M: Risk factors for perinatal mortality in dairy cattle: cow and foetal factors, calving process. Theriogenology 2009, 71:901-909.

33. Mee JF: The role of the veterinarian in bovine fertility management on modern dairy farms. Theriogenology 2007, 68(Suppl 1):257-265.

34. Mee JF, Berry DP, Cromie AR: Risk factors for calving assistance and dystocia in pasture-based Holstein-Friesian heifers and cows in Ireland. Vet J 2011, 187:189-194.

35. Becker M, Tsousis G, Lupke M, Goblet F, Heun C, Seifert H, Bollwein H: Extraction forces in bovine obstetrics: an in vitro study investigating alternate and simultaneous traction modes. Theriogenology 2010, 73:1044-1050.

36. Sorge U, Kelton D, Staufenbiel R: Neonatal blood lactate concentration and calf morbidity. Vet Rec 2009, 164:533-534.

37. Schuijt G, Taverne MA: The interval between birth and sternal recumbency as an objective measure of the vitality of newborn calves. Vet Rec 1994, 135:111-115. 
38. Houwing $H$, Hurnik JF, Lewis NJ: Behaviour of periparturient dairy cows and their calves. Can J Anim Sci 1990, 70:355-362.

39. Uystepruyst C, Coghe J, Dorts T, Harmegnies N, Delsemme M-H, Art T, Lekeux P: Sternal recumbency or suspension by the hind legs immediately after delivery improves respiratory and metabolic adaptation to extra uterine life in newborn calves delivered by caesarean section. Vet Res 2002, 33:709-724.

40. Uystepruyst C, Coghe J, Dorts T, Harmegnies N, Delsemme MH, Art T, Lekeux P: Effect of three resuscitation procedures on respiratory and metabolic adaptation to extra uterine life in newborn calves. Vet J 2002 163:30-44.

41. Mee JF: Resuscitation of newborn calves-materials and methods. Cattle Pract 1994, 2:197-210.

42. Bleul U, Bircher B, Jud RS, Kutter APN: Respiratory and cardiovascular effects of doxapram and theophylline for the treatment of asphyxia in neonatal calves. Theriogenology 2010, 73:612-619.

43. Bleul UT, Schwantag SC, Kahn WK: Effects of hypertonic sodium bicarbonate solution on electrolyte concentrations and enzyme activities in newborn calves with respiratory and metabolic acidosis. Am J Vet Res 2007, 68:850-857.

44. Bleul UT, Bircher BM, Kahn WK: Effect of intranasal oxygen administration on blood gas variables and outcome in neonatal calves with respiratory distress syndrome: 20 cases (2004-2006). J Am Vet Med Assoc 2008, 233:289-293.

45. Gorden PJ, Plummer P: Control, management, and prevention of bovine respiratory disease in dairy calves and cows. Vet Clin North Am Food Anim Pract 2010, 26:243-259.

46. Waltner-Toews D, Martin SW, Meek AH: Dairy calf management, morbidity and mortality in Ontario Holstein herds. IV. Association of management with mortality. Prev Vet Med 1986, 4:159-171.

47. Godden S: Colostrum management for dairy calves. Vet Clin N Am: Food Anim Pract 2008, 24:19-39.

48. Boyd JW: The relationship between serum immune globulin deficiency and disease in calves: a farm survey. Vet Rec 1972, 90:645-649.

49. Roy JHB: Factors affecting susceptibility of calves to disease. J Dairy Sci 1980, 63:650-664.

50. Fallon RJ, Harte FJ: The occurrence of diarrhoea in calves under different management systems. Ann Rech Vet 1983, 14:473-478.

51. Tyler JW, Hancock DD, Wiksie SE, Holler SL, Gay JM, Gay CC: Use of serum protein concentration to predict mortality in mixed-source dairy replacement heifers. J Vet Intern Med 1998, 12:79-83.

52. McGee M, Drennan MJ, Caffrey PJ: Effect of suckler cow genotype on cow serum immunoglobulin (lg) levels, colostrum yield, composition and Ig concentration and subsequent immune status of their progeny. Irish $J$ Agr Food Res 2005, 44:173-183.

53. Earley B, McGee M, Fallon RJ, Drennan MJ, Murray M, Farrell JA: Serum immunoglobulin concentrations in suckled calves and dairy-herd calves. Irish J Agr Food Res 2000, 39:401-407.

54. Murphy BM, Drennan MJ, O'Mara FP, Earley B: Cow Serum and Colostrum Immunoglobulin (lgG) Concentration of Five Suckler Cow Breed Types and Subsequent Immune Status of Their Calves. Irish J Agr Food Res 2005, 44:205-213.

55. Muller LD, Ellinger DK: Colostral immunoglobulin concentrations among breeds of dairy cattle. J Dairy Sci 1981, 64:1727-1730.

56. Pritchett LC, Gay CC, Besser TE, Hancock DD: Management and production factors influencing immunoglobulin G1 concentration in colostrum from Holstein cows. J Dairy Sci 1991, 74:2336-2341.

57. Tomkins T, Jaster EH: Preruminant calf nutrition. Vet Clin North Am Food Anim Pract 1991, 7:557-576.

58. Chigerwe M, Tyler JW, Middleton JR, Spain JN, Dill JS, Steevens BJ: Comparison of four methods to assess colostral lgG concentration in dairy cows. J Am Vet Med Assoc 2008, 233:761-766.

59. Chigerwe M, Tyler JW, Schultz LG, Middleton JR, Steevens BJ, Spain JN: Effect of colostrum administration by use of oroesophageal intubation on serum IgG concentrations in Holstein bull calves. Am J Vet Res 2008, 69:1158-1163.

60. Chigerwe M, Tyler JW, Summers MK, Middleton JR, Schultz LG, Nagy DW: Evaluation of factors affecting serum IgG concentrations in bottle-fed calves. J Am Vet Med Assoc 2009, 234:785-789.

61. Morin DE, Nelson SV, Reid ED, Nagy DW, Dahl GE, Constable PD: Effect of colostral volume, interval between calving and first milking, and photoperiod on colostral lgG concentrations in dairy cows. J Am Vet Med Assoc 2010, 237:420-428.

62. Bielmann V, Gillan J, Perkins NR, Skidmore AL, Godden S, Leslie KE: An evaluation of Brix refractometry instruments for measurement of colostrum quality in dairy cattle. J Dairy Sci 2010, 93:3713-3721.

63. Stott GH, Marx DB, Menefee BE, Nightengale GT: Colostral immunoglobulin transfer in calves I. Period of absorption. J Dairy Sci 1979, 62:1632-1638.

64. Stott GH, Marx DB, Menefee BE, Nightengale GT: Colostral immunoglobulin transfer in calves II. The rate of absorption. J Dairy Sci 1979, 62:1766-1773.

65. Berge AC, Besser TE, Moore DA, Sischo WM: Evaluation of the effects of oral colostrum supplementation during the first fourteen days on the health and performance of preweaned calves. J Dairy Sci 2009, 92:286-295.

66. Kaske M, Werner A, Schuberth HJ, Rehage J, Kehler W: Colostrum management in calves: effects of drenching vs. bottle feeding. J Anim Physiol Anim Nutr 2005, 89:151-157.

67. Godden SM, Haines DM, Konkol K, Peterson J: Improving passive transfer of immunoglobulins in calves. II: Interaction between feeding method and volume of colostrum fed. J Dairy Sci 2009, 92:1758-1764.

68. USDA: Dairy 2007, Heifer Calf Health and Management Practices on U.S. Dairy Operations, 2007. USDA:APHIS:VS, CEAH Fort Collins, CO \#5500110 2010.

69. Lipp K: Feldstudie zur kolostralen Immunglobulin-Versorgung neugeborener Kälber in Abhängigkeit von der Verweildauer beim Muttertier. Thesis, University of Munich 2005.

70. Besser TE, Gay CC, Pritchett L: Comparison of three methods of feeding colostrum to dairy calves. J Am Vet Med Assoc 1991, 198:419-442.

71. Meylan M, Rings DM, Shulaw WP, Kowalski JJ, Bech-Nielsen S, Hoffsis GF: Survival of Mycobacterium paratuberculosis and preservation of immunoglobulin $\mathrm{G}$ in bovine colostrum under experimental conditions simulating pasteurization. Am J Vet Res 1996, 57:1580-1585.

72. Godden SM, Smith S, Feirtag JM, Green LR, Wells SJ, Fetrow JP: Effect of on-farm commercial batch pasteurization of colostrum on colostrum and serum immunoglobulin concentrations in dairy calves. J Dairy SC 2003, 86:1503-1512.

73. McMartin S, Godden SM, Metzger L, Feirtag J, Bey R, Stabel J, Goyal S, Fetrow J, Wells S, Chester-Jones H: Heat treatment of bovine colostrum I: Effects of temperature on viscosity and immunoglobulin G level. J Dairy Sci 2006, 89:2110-2118.

74. Elizondo-Salazar JA, Heinrichs AJ: Feeding heat-treated colostrum to neonatal dairy heifers: Effects on growth characteristics and blood parameters. J Dairy Sci 2009, 92:3265-3273.

75. Mee JF, O'Farrell KJ, Reitsma P, Mehra R: Effect of a whey protein concentrate used as a colostrum substitute or supplement on calf immunity, weight gain, and health. J Dairy Sci 1996, 79:886-894.

76. Godden SM, Haines DM, Hagman D: Improving passive transfer of immunoglobulins in calves. I: dose effect of feeding a commercial colostrum replacer. J Dairy Sci 2009, 92:1750-1757.

77. Smith GW, Foster DM: Short communication: Absorption of protein and immunoglobulin $\mathrm{g}$ in calves fed a colostrum replacer. J Dairy Sci 2007, 90:2905-2908.

78. Jones LR, Taylor AW, Hines HC: Characteristics of frozen colostrum thawed in a microwave oven. J Dairy Sci 1987, 70:1941-1945.

79. Davis $\mathrm{CL}$, Drackley JK: The development, nutrition, and management of the young calf Ames, lowa: lowa State University Press; 1998.

80. Tyler JW, Hancock DD, Parish SM, Rea DE, Besser TE, Sanders SG, Wilson LK: Evaluation of 3 assays for failure of passive transfer in calves. J Vet Intern Med 1996, 10:304-307.

81. Weaver DM, Tyler JW, VanMetre DC, Hostetler DE, Barrington GM: Passive transfer of colostral immunoglobulins in calves. J Vet Intern Med 2000, 14:569-577.

82. Jasper J, Weary DM: Effects of ad libitum milk intake on dairy calves. $J$ Dairy Sci 2002, 85:3054-3058.

83. NRC: Nutrient requirements of dairy cattle (National Research Council). 7 edition. Washington, DC: National Academy Press; 2001.

84. Kertz AF, Prewitt LR, Everett JP Jr: An early weaning calf program: summarization and review. J Dairy Sci 1979, 62:1835-1843.

85. Woodward TE: The optimum quantity of skim milk for calf feeding. J Dairy Sci 1923, 6:243-244.

86. Marshall SP, Smith KL: Effect of different milks and levels of intake upon growth of young dairy calves. J Dairy Sci 1970, 53:1622-1626. 
87. Diaz MC, Van Amburgh ME, Smith JM, Kelsey JM, Hutten EL: Composition of growth of Holstein calves fed milk replacer from birth to 105kilogram body weight. J Dairy Sci 2001, 84:830-842.

88. Flower FC, Weary DM: Effects of early separation on the dairy cow and calf: 2 . Separation at 1 day and 2 weeks after birth. Appl Anim Behav SCl 2001, 70:275-284.

89. Nonnecke BJ, Foote MR, Smith JM, Pesch BA, Van Amburgh ME: Composition and functional capacity of blood mononuclear leukocyte populations from neonatal calves on standard and intensified milk replacer diets. J Dairy Sci 2003, 86:3592-3604.

90. Bartlett KS, McKeith FK, VandeHaar MJ, Dahl GE, Drackley JK: Growth and body composition of dairy calves fed milk replacers containing different amounts of protein at two feeding rates. J Anim Sci 2006, 84:1454-1467.

91. Appleby MC, Weary DM, Chua B: Performance and feeding behaviour of calves on ad libitum milk from artificial teats. Appl Anim Behav Sci 2001, 74:191-201.

92. Woodward B: Protein, calories, and immune defenses. Nutr Rev 1998, 56:84-92.

93. Drackley JK: Early growth effects on subsequent health and performance of dairy heifers. In Calf and heifer rearing. Edited by: Garnsworthy PC. Nottingham: Nottingham University Press; 2005:213-235.

94. Williams PEV, Day D, Raven AM, McLean JA: The effect of climatic housing and level of nutrition on the performance of calves. Animal Science 1981, 32:133-141.

95. Godden SM, Fetrow JP, Feirtag JM, Green LR, Wells SJ: Economic analysis of feeding pasteurized nonsaleable milk versus conventional milk replacer to dairy calves. J Am Vet Med Assoc 2005, 226:1547-1554.

96. Khan MA, Lee HJ, Lee WS, Kim HS, Ki KS, Hur TY, Suh GH, Kang SJ, Choi YJ: Structural growth, rumen development, and metabolic and immune responses of Holstein male calves fed milk through step-down and conventional methods. J Dairy Sci 2007, 90:3376-3387.

97. SVC: Report on the Welfare of Calves. Scientific Veterinary Committee, Animal Welfare Section. Directorate Generale for Agriculture, VI/BII.2. Adopted November 9, 1995 1995, 120.

98. Selim SA, Cullor JS: Number of viable bacteria and presumptive antibiotic residues in milk fed to calves on commercial dairies. J Am Vet Med Assoc 1997, 211:1029-1035.

99. Dolejska M, Senk D, Cizek A, Rybarikova J, Sychra O, Literak I: Antimicrobial resistant Escherichia coli isolates in cattle and house sparrows on two Czech dairy farms. Res Vet Sci 2008, 85:491-494.

100. Drackley JK: Calf nutrition from birth to breeding. Vet Clin North Am Food Anim Pract 2008, 24:55-86.

101. Hill TM, Bateman HGn, Aldrich JM, Schlotterbeck RL: Optimizing nutrient ratios in milk replacers for calves less than five weeks of age. J Dairy Sci 2009, 92:3281-3291.

102. Galton DM, Brakel WJ: Influence of feeding milk replacer once versus twice daily on growth, organ measurements, and mineral content of tissues. J Dairy Sci 1976, 59:944-948.

103. Gleeson D, O'Brien B, Fallon RJ: Feeding of cold whole milk once daily to calves in a group and its effect on calf performance, health, and labour input. Intern J Appl Res Vet Med 2007, 5:97-104.

104. Gleeson D, O'Brien B, O'Donovan K: The labour input associated with calf care on Irish dairy farms. Livest Sci 2008, 116:82-89.

105. Khan MA, Lee HJ, Lee WS, Kim HS, Kim SB, Ki KS, Ha JK, Lee HG, Choi YJ: Pre- and post-weaning performance of Holstein female calves fed milk through step-down and conventional methods. J Dairy Sci 2007, 90:876-885.

106. Hill TM, Bateman HGn, Aldrich JM, Schlotterbeck RL: Effects of the amount of chopped hay or cottonseed hulls in a textured calf starter on young calf performance. J Dairy Sci 2008, 91:2684-2693.

107. Jasper J, Budzynska M, Weary DM: Weaning distress in dairy calves: Acute behavioural responses by limit-fed calves. Appl Anim Behav Sci 2008, 110:136-143.

108. Nielsen PP, Jensen MB, Lidfors L: Milk allowance and weaning method affect the use of a computer controlled milk feeder and the development of cross-sucking in dairy calves. Appl Anim Behav Sci 2008, 109:223-237.

doi:10.1186/2046-0481-64-10

Cite this article as: Lorenz et al:: Calf health from birth to weaning. I.

General aspects of disease prevention. Irish Veterinary Journal 2011 64:10.

\section{Submit your next manuscript to BioMed Central and take full advantage of:}

- Convenient online submission

- Thorough peer review

- No space constraints or color figure charges

- Immediate publication on acceptance

- Inclusion in PubMed, CAS, Scopus and Google Scholar

- Research which is freely available for redistribution 